\title{
A Brief Analysis on the Present Situation and Countermeasures of the Management of Secondary Colleges in Private Colleges
}

\author{
Xiaorong Xia \\ Accounting Institute, Xi'an Peihua University, Xi'an, 7101215, China
}

Key words: Private universities, Secondary college, Management.

\begin{abstract}
In China.with the continuous development of non-government colleges and universities, the scale and quantity of them are increasing greatly. In order to adapt to the education development in the transitional period, the colleges and universities are constantly strengthening their own strength, improving their core competitiveness, and establishing their own competitive advantages. Some of them have canceled the old teaching department and begin to establish the institute system management. Aiming at the problems arising in the institute system management of non-government colleges and universities, in this paper, the author first analyzes the management status and some problems in non-government universities, then puts forward some countermeasures from some aspects such as establishing institute system, organizational structure, and distribution of power,etc. hoping to provide the evidence to the organizational operation and management system of private-universities in China.
\end{abstract}

\section{Introduction}

In the general background of the world and China's education, our public and private education show a common development pattern. But in recent years, the number of students taking college entrance examination has fallen, there is a shortage of students in universities, competition in the enrollment market is fierce. The size and number of private colleges and universities are also increasing. In order to adapt to the development of education in the transition period, colleges and universities are constantly expanding their strengths, improving their core competitiveness, establishing own competitive advantage. They are first to build hardware, buy land through financing to continuous expand the campus and purchase experimental training equipment, strengthen the cooperation between college and enterprise, buy book resources to provide a comfortable, efficient learning and working environment for teachers and students, eventually, won a place in the fierce competition.

Secondly, colleges and universities are also strengthening the construction of faculty, introduce in highly educated and high-level talents with big salary. Some universities already have introduction plan for hundreds of PHDS. In addition to this, they also continued to strengthen visit learning with peer colleges, and strengthen cooperation and communication with enterprises, and integrate innovative ideas into teaching and management, thus to show their the school-running characteristics and specialized characteristic.

When hardware and software are available at the same time, through assessment, private schools have started to change their names, try to upgrade to "college". Meanwhile, institutions within the college have also begun to reform. From the former three levels management "College -- department -- teaching and research office" to "College -- secondary college -- department -- teaching and research office" or "College -- secondary college -- teaching and research office". The secondary college sets the functional departments according to the actual requirements. How to set up functional departments in each college is based on the secondary college situation. However, the establishment of the secondary college in each private college presents the phenomenon of all flowers are in bloom. There is a big difference between different private colleges and universities in terms of nature, scale and setting. 


\section{Concept definition}

\section{Private college}

Since reform and opening up, great changes have taken place in our society, economy and politics, private colleges and universities have also developed rapidly with the tide of reform. Investigation indicates that in 2010, there were 676 private colleges in China, which includes 323 independent institutions. The number of students at school is 4.7668 million, accounts for more than $20 \%$ of the total number of college students. It is visible that private colleges and universities have become the important force in the country's higher education.

Private colleges refers to higher education schools established by enterprise and public institution, social organization or citizen by virtue of non-state financial resources according to the establish standards established by state and the local ministry of education. In order to comply with national policies, adapt to market development, ensure own competitive edge, private colleges and universities should carry out continuous reform and improvement to the internal management system and organization institutions.

In recent years, in order to adapt to market competition and keep up with the pace of economic development, every college, no matter its size, is reforming its organizational structure to varying degrees. Some universities merge to better integrate education resources; come colleges have changed their name in order to broaden their enrollment; also some colleges and universities change from "college" to "university" to raise the level of education. But in the process of college rising, college organizations have different types.

\section{Secondary college}

The implementation of college system in colleges and universities in China can be traced back to the University Organization Law promulgated by the national government in 1929, it stipulates that the university has eight colleges, which are language, science, law, education, agriculture, industry, commerce and medicine, with more than three colleges can be called university, only one or two colleges, can just called as independent college. There is a great adjustment in 1952, universities have abolished colleges, implementation of two levels of management of university and department. Later, with higher education discipline were highly differentiated and with the integrated development trend, the wide - span university-department, two - level management mode management of colleges and universities are somewhat stretched, the college system is coming up.

\section{Present situation and existing problems of secondary college management}

In order to investigate the present situation and structure of secondary colleges in various private colleges and universities, the author visited three private universities in Shaanxi province, with deep feelings. The first one visited was A college, the basic situation of this college is that it is with a long history, but slow development. Because there are fewer students, the scale is not up to a certain level. Although the original department was renamed xx college, in terms of structure and system, the old management system was inherited. There is no change in management level and management range.

The second college I visited was B college, it is independent undergraduate, it is one of the three universities affiliated to a public university. Opening time is late. Because it relies on a public university, so it can get into orbit quickly, both in terms of enrollment and management. This structure was used in the early days of the college "College -- secondary college -- teaching and research office", as following(Fig. 1): 


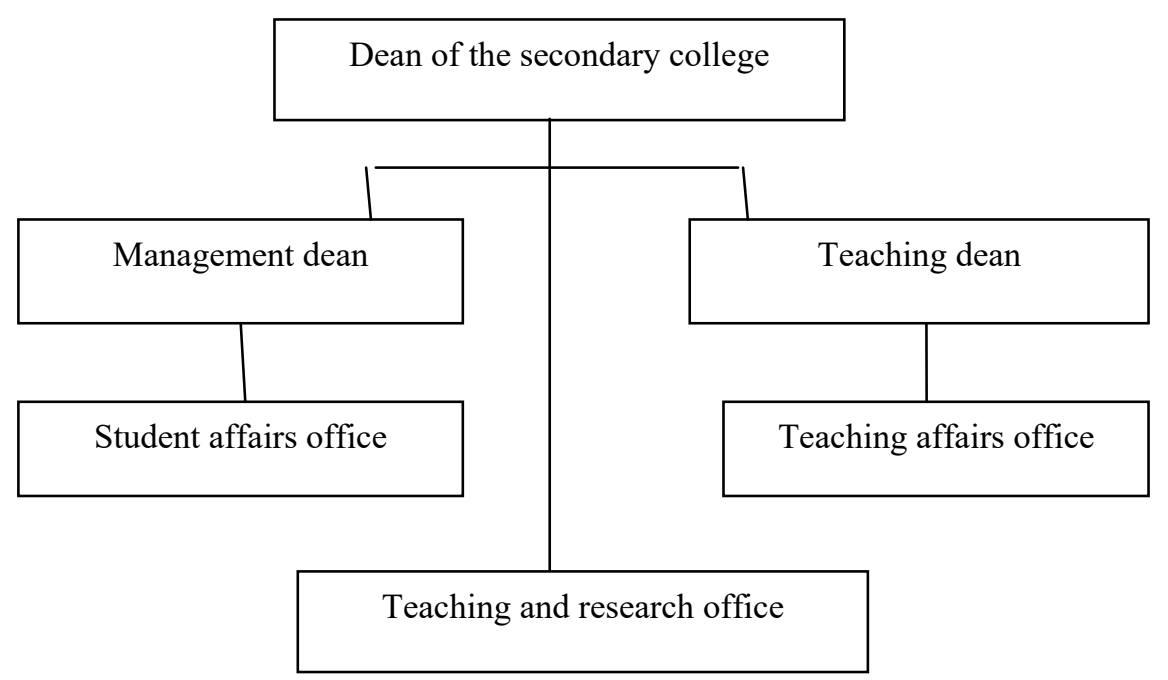

Fig. 1. A simplified organization structure of the secondary college of B college

The third college I visited was $\mathrm{C}$ college, it run a long time, with a large scale, it is a comprehensive private undergraduate college, currently, there are over 20,000 students, it has ten secondary branches, has its own school-running characteristics, the accounting major is its star major, the accountancy college is also the first known college. The accountancy college has over 7,000 students, more 130 teaching staffs. Its organizational chart is as following(Fig. 2):

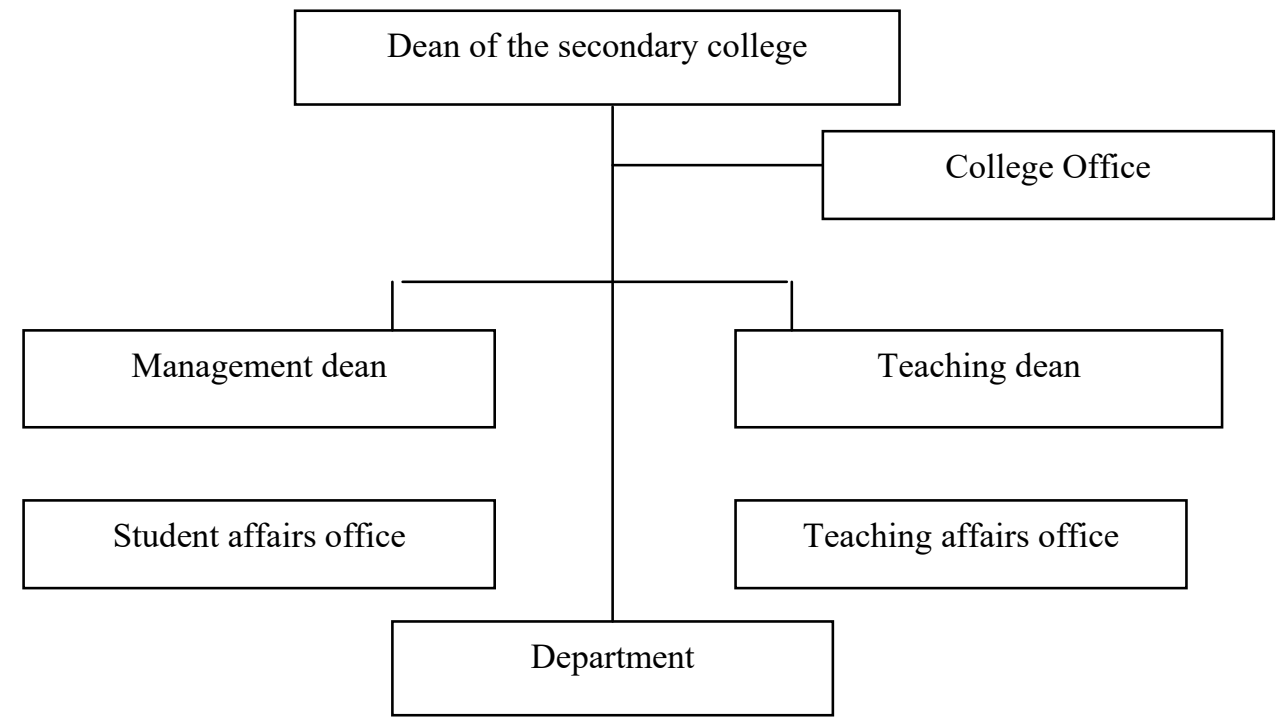

Fig. 2. A simplified organization structure of the secondary college of C college

By visiting survey we found that at present, the establishment and management of secondary colleges in various private colleges have the following problems:

\section{The secondary college is blindly set up, which is not correspondent with practice}

Visit survey found that many private universities show blindness in the establishment of colleges, which is not correspondent with practice. Such as A college, there are fewer than ten thousand students in the university, the admission conditions of different major, good and bad are intermingled, to highlight its characteristics and Raise awareness. It set the original department to the college, still used the original management system.

\section{Organizational setup is not reasonable, poor organization}

Investigation reveals that most private colleges have no uniform standards for the organization of secondary colleges. How to set up the organization is according to the actual situation. The current representative secondary college organization is shown below: 


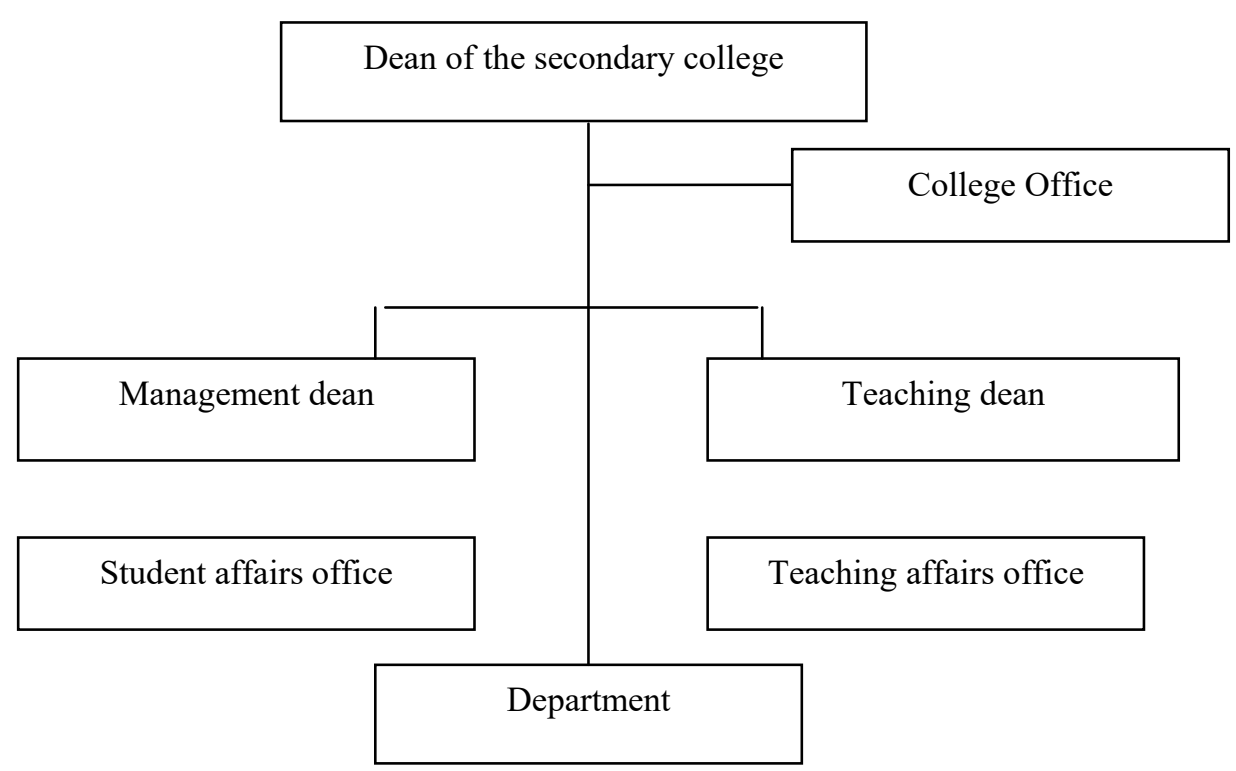

Fig. 3. A simplified organization structure of XX secondary college

This kind of organization has following problems in operation: firstly, the administrator is overloaded, need to deal with both administrative affairs and academic issues; secondly, the staff is not accountable, inefficiency, with coordination difficulties; thirdly, job is complicated, there are often double leaders.

\section{Administrator lack decision-making autonomy, management inefficiencies}

At present, many private colleges and universities have set up secondary colleges, try the college system management. Though the institutions have been reformed and restructured, but the college management focus has not shifted, power is not delegated. The main decision-making powers remain concentrated in the hands of senior school administrators.

\section{The staffing is not reasonable, employees are not motivated}

Because colleges and universities do not pay enough attention to the management of secondary colleges, it's hard to deploy some very good talents into secondary colleges, which cause the professional quality of the college management team is not high. With the modernization of university management, it is difficult for these administrators to adapt to the higher degree of professional management.

\section{The management strategy of secondary college}

\section{Set up the correct principles of college setting}

Secondary colleges in private colleges are an important part of the organizational structure of it. Under the new college system, In order to improve the quality of personnel training, to promote the vitality of school education, to establish the college's characteristics, it is very important to formulate and research the establishment principle of secondary college and to formulate the organizational structure and implementation strategy of the two levels management.

Set up secondary colleges to be scientific and standardized

Follow scientific principle is to emphasize the position of science. The positioning of secondary college is closely related to regional economic development, college professional planning and specialty construction. Through various majors research to look for commonalities and personalities, to analyze the market situation and the development of the college, and make scientific positioning.

The secondary college should pay attention to inheritance and development

The secondary college should integrate its running characteristics and running and teaching conception, refine the characteristics of the major and inheriting and developing according to the 
regional economy development and the demand for talents.

Secondary colleges should focus on nurturing and innovation

Secondary colleges should straighten out the relationship of colleges and universities, implement decentralize management. Not only need to follow the path of the college, but also take into consideration the principle of inheritance, development and innovation, establish the institute status, follow the authority of the college; stimulate the vitality of the college to management and operation systems of self-accumulation, self-development, self-discipline, and take this as the starting point for innovation.

\section{Set up a reasonable organization}

As the internal and external environment of the enterprise changes, in order to meet these opportunities and challenges, enterprises need to continuously integrate resources and change internal organizational structure. The development of enterprises is inseparable from organizational change, colleges are no exception. Many scholars have also studied the establishment of secondary colleges. In this paper, the author mainly puts forward the structure of linear vocational structure to learn from the structure of secondary colleges. Linear functional organization structure is the most widely used organization form in reality, it combines the linear structure with the functional structure, based on the line, the corresponding functional departments shall be established under the administrative heads of all levels, respectively for professional management, as an adviser to the leader, to carry out the organizational structure of the unified command and functional departments. In the expanding private colleges, the structure of secondary colleges can also refer to this form, as shown in Fig. 4.

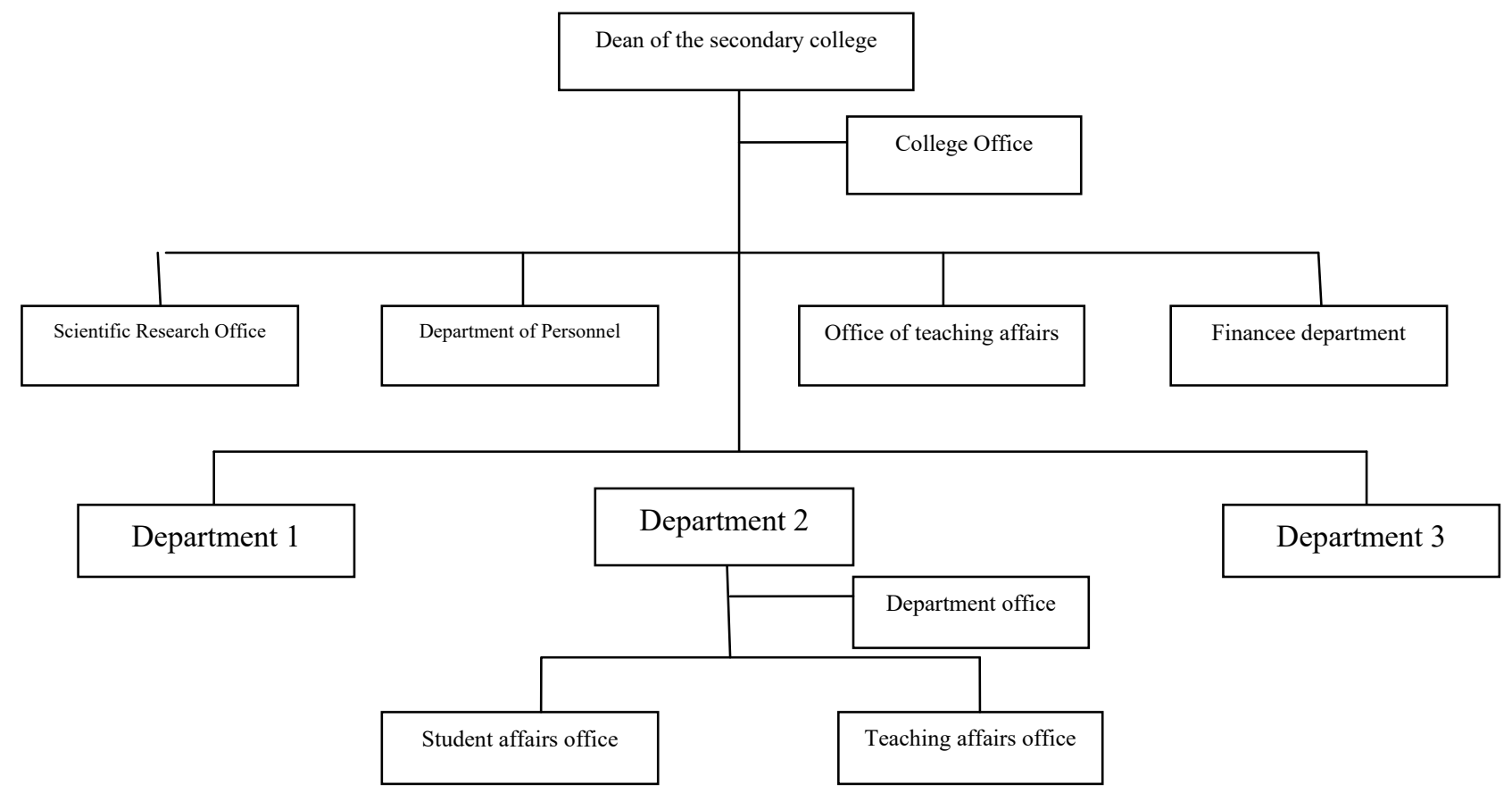

Fig. 4. line and staff organization organization chart

This organizational structure can completely solve the management problems that secondary colleges currently face. Firstly, Linear functional system will be meticulous, clear division of labor, clear responsibility and high efficiency; secondly, it can guarantee unified command, avoid the politics of multiple doors, the appearance of management chaos; at last, the stability of this structure is stronger, when the external environment changes little, it is easy to exert the group efficiency of the organization, and thus can better serve the management work.

\section{Decentralization}

Decentralization means to shift the power that concentrated in university to the secondary college. Implement management model combining centralization and decentralization. However, in practice, 
it should be examined and approved, with complex program, inefficiency. Universities should allow each secondary college to spend on its own budget. Besides, college should also have independent power in teaching, scientific research and discipline construction, make it more free for work, and continuously improve the quality of teaching and the academic level.

\section{Staffing reasonable}

Staffing is a very important part of enterprise management, also the basic link of the company's talent gradient construction. The following principles should be followed:

First of all, focus on the economic benefits of the organization. Staffing should be planned based on the economic benefits of the organization, should not blindly expand the teachers' team or post vacancies.

Secondly, focus on talent. Staffing should be realistic and selfless. We should attach importance to talents, find talents, develop a spirit of seeking for the better, and attach importance to and use the people who are both active and conscientious. This is the key for productivity improvement.

Thirdly, make the best use of talents and things. Put the right person in the right place. Everyone has a different by nature. When select talent, manager should give full play to one's personal strengths, assign each employee to his or her best position, thus can improve work efficiency.

In a word, personnel allocation is very important in the secondary college organization operation, reasonable personnel allocation avoids the confusion about duties and responsibilities, low working efficiency and prevarication. Reasonable staffing is the key for the develop and grow of the organization.

\section{Conclusion}

With the steady development and growth of China's private colleges scale, the college system is becoming more and more common, aims at the problems existing in the system management of private colleges and universities, the author puts forward some suggestions, hope to provide basis for the organization operation mechanism and management system of private universities. Besides, colleges should also combine their own development and actual situation to choose the management system and organization that meet the development of this college, put in place relevant operation policy, set the overall goal of college development, actively research and explore the difficult task of the school system management system, then combine with reality, apply new ideas and innovative ideas to solve practical problems, and form a set of complete and constantly updated theoretical system, all these are the theoretical basis for the internal management of private universities in China and contribute to the development of China's private universities.

\section{References}

[1] Deng Guoli. Principles and implementation strategies of setting secondary college of higher vocational colleges, Journal of Shenzhen institute of information technology, 2012.(12).

[2] Fang Feihu. Understanding and thinking of second-level management system implementation in higher vocational colleges, Vocational Education Research, 2008.(1).

[3] Ju Liying. Analysis on the management and reform of secondary management in higher vocational colleges, Journal of Changzhou information technology institute, 2007. (5).

[4] Li Weimin. Analysis on Shanxi Private Colleges, Private Education Research, 2002,(1).

[5] Li Qunying. Research on the reform of China's secondary college management structural, Guangxi Normal University, 2003.

[6] Chen Xiaobin. Educational Administration, Beijing: Beijing Normal University Press, 1999,(12).

[7] Su Dongshui. Management Science, Shanghai: Oriental publishing center,2001,(08). 
[8] Huang Teng. Private education search, Xi'an: Shaanxi people's publishing press,2002.

[9] Notification on further promote National demonstration higher vocational college construction plan, Teaching, No. 2010,8.

[10]Notification on supporting higher vocational colleges to improve professional service industry development ability, Teaching facility No.2011,11. 